\title{
An examination of the characteristics of mothers neglecting their children
}

\author{
Ferda Karadağ ${ }^{1 \oplus}$, Dilşad Foto Özdemir ${ }^{2 \odot}$, Gülin Evinç ${ }^{2 \odot}$ Esra Çalık Var ${ }^{3 \odot}$, \\ Cengiz Özbesler ${ }^{3 \odot}$
}

${ }^{1}$ Department of Social Work, Faculty of Health Sciences, Bartm University, Bartm; ; ${ }^{2}$ eepartment of Child and Adolescent Mental Health Hacettepe University Faculty of Medicine, Ankara; ${ }^{3}$ Department of Social Work, Faculty of Health Sciences, Ankara Yildirım Beyazıt University, Ankara, Turkey.

\begin{abstract}
Background. This study is aimed to recognize families who have neglected their children in the early period, to raise awareness among experts especially pediatricians-working in this field about the reasons contributing to the neglect.
\end{abstract}

Methods. For this purpose, data were collected by quantitative and qualitative methods. The mothers of 32 neglected children and 30 children who were not neglected were included in to the study. Sociodemographic Information Form, Neglect Assessment Tool, Close

Relationships Inventory, Perceived Social Support Scale, Marital Adjustment Scale, Childhood Trauma Survey Scale, Semi Structured Interview Form, SCID I and SCID II were used as data collection tools. T-test, ANOVA, Chi-square test, Kruskal Wallis, Pearson Correlation test were used for quantitative analysis and descriptive analysis method was used in the analysis of qualitative data.

Results. In the quantitative findings obtained; mothers of neglected children and control group mothers differed in terms of their age, income perceptions, multidimensional perceived social support, marital adjustment, physical and emotional abuse subscales on the scale of childhood abuse, adult attachment patterns, however; it was found that there was no difference in terms of mental illness and personality disorder, and scores on sexual abuse subscale of child abuse. Qualitative results demonstrated that most of the mothers did not consider themselves adequate for parenting, were not satisfied with their parenting role, had insufficient emotional investment in their children and could not balance their roles.

Conclusions. It was concluded that the mothers of neglected children had problems in the areas of social support, marital adjustment, adult attachment patterns and they were also exposed to physical and emotional abuse during their own childhood and these problems negatively affected the quality of their childcare. For this reason, it is important to provide support to neglectful families and family interventions should be established.

Key words: child neglect, maternal characteristics, risk factors for child neglect.

Child neglect occurs when a child's basic needs are not met. ${ }^{1}$ Researches report that neglect can sometimes lead to more serious consequences

Ferda Karadağ
fkaradag@bartin.edu.tr

Received 8th June 2020, revised 27th June 2020, 24th July 2020, accepted 4th August 2020.

This article is part of a doctoral thesis named "An Examination of the Characteristics of Mothers Neglecting Their Children: A Mixed Method Research". than abuse. Neglected children are reported to have more physical, emotional or cognitive health problems, accidents, injuries or even death when there is a delay in treatment or safety precautions are not taken. ${ }^{2-10}$ Since neglect can have tragic consequences, timely and effective interventions are crucial and as the primary caregiver, more attention was given to mothers in neglect. ${ }^{5,11}$

Studies have shown that there are significant differences between parents who neglect and 
do not neglect their children. ${ }^{5,11}$ In many studies, low income, low education level, being a mother at a young age and single parent families are described as risk factors for neglect., ${ }^{5,2-20}$ However, there are studies indicating that having adequate social support reduces the level of stress of mothers, which positively affects parenting attitudes and skills of mothers and as a result it facilitates their coping with problems and reduces their neglectful behavior. ${ }^{21-25}$ In addition to demographic characteristics and social support, some psychological factors are also known to determine the quality of the mother's relationship with their children. It is also stated that most mothers who neglect their children have a history of one or more psychiatric disorders. ${ }^{26-28}$ Similarly, it has been stated that parents who have conflict in the marriage cannot pay attention to their children's needs. ${ }^{29}$ In addition, these parents have some features such as inadequate organization skills, less verbal communication, less expression of positive feelings and more expression of negative feelings..$^{30}$ The relationship between negligent mothers and their parents has also been mentioned, and it has been shown in many studies that the mother, who has a close, reliable relationship with her own parent, has secure attachment styles, meets the needs of her own child quickly and sensitively. ${ }^{31-33}$ On the other hand, it has been shown in many studies that mothers' own childhood abuse experiences negatively affect the quality of caring for their own children. ${ }^{34-38}$ MacPhee et al. ${ }^{39}$ stated that the perception of parenting affects parental activities and plays a role in the development of children. Parental selfperception has been determined as to the extent to which an individual sees herself as a caregiver, has satisfaction with this role, invests in caregiving, and whether the individual can balance the mother role with other roles. Although there are studies conducted in the literature with the perception of parenting, ${ }^{40-45}$ this issue has not been investigated in a sample of mothers of neglected children. It is thought that understanding perceptions of parenting is important to understand the cause of child neglect and prepare effective intervention programs.

Child neglect is an important issue to be considered and it is necessary to know which features of parents play a role in neglect. ${ }^{12,46}$ The main goal of this research is therefore to raise awareness among professionals about the causes of child neglect. For this purpose, perceptions and experiences of motherhood, variables that may affect the caregiving competencies of the mothers whose children applied to the hospital due to another health problem and considered to be neglected in the evaluation, were examined. This research focuses on the various characteristics of mothers who are evaluated within the context of risk factors in child neglect.

\section{Material and Methods}

\section{Participants and Procedure}

The sample of the study consists of the mothers of children between the ages of 0-6 who were brought to different outpatient clinics of Hacettepe University Children's Hospital by their families.

Mothers of pre-school children were included in the study because of the fact that pre-school children are at higher risk of neglect and in these population, prevention and intervention strategies become important. The mothers in the study were divided into two groups as the mothers of neglected children and mothers of the control group. The mothers of 34 children who were considered to be neglected as a result of their history and examination (retardation in their cognitive, emotional and social development that could not be explained by medical findings, inadequate personal hygiene, application to the hospital with various accidents and injuries, disrupting their medical controls) were directed to the researcher. A home visit was made to these families by the researcher, and in cases of suspected negligence the observation and interview was carried out for 2 hours at home, using the "Graded 
Care Profile" which targets understanding the severity of the situation and determine the areas of intervention. According to The Graded Care Profile, 2 mothers who did not meet the neglect criteria were excluded from the study and 32 mothers were included in the mothers of neglected children. The control group consisted of the mothers of 30 children who were brought to the hospital for reasons such as vaccination, medical consultation, and simple medical interventions. The criterion for inclusion in the control group was the absence of children's developmental problems and the lack of a history suggesting neglect, and also the mothers being parents who took care of their children and who have a healthy motherchild relationship. 8 of the mothers who neglected their children were selected for the qualitative analysis, giving importance to diversity according to some properties such as age, education, socioeconomic level, number of children, and history of psychiatric disorder. As a result, the qualitative sample of the study was created. In order to ensure that the group is homogeneous, the mothers being the primary caregiver, having a cognitive level that can understand and fill the data collection tools, the absence of a chronic illness or disability of their children, and living with their spouses were determined as the inclusion criteria of this research.

The study was conducted in accordance with the Helsinki declaration, and the Ethics Committee of the Non-Interventional Clinical Researches of Hacettepe University approved the study (decision number: 17/142-05, date: 2017/07) and consent form was taken from the participants.

\section{Measurements}

The Graded Care Profile: It was developed by Srivastava and Polnay ${ }^{47}$ as a tool to identify and evaluate neglect in children. It was created as a descriptive, categorical tool in order to make reliable decisions about the quality of care taken by children and to make decisions not subjective and biased. It provides the opportunity to evaluate parents by observing four areas of care, including physical care, safety, love and esteem at home. The consistency coefficients of the tool between the different practitioners were found to be 0.89 for physical care subscale, 0.89 for safety subscale, 0.79 for love subscale, 0.87 for esteem subscale, and it was found to be a reliable tool for detecting neglect. ${ }^{48}$ The scale in the original language was translated into Turkish by the two experts and the experts reviewed each other's scale. In the second step, the experts turned the questionnaire back to the original language and then the original language and the translated formats were compared with each other, and the translation was finalized by making the necessary corrections.

Sociodemographic Data Form: This form was prepared by the researcher to understand the sociodemographic features of mothers and some features related to their children.

Multidimensional Scale of Perceived Social Support, (MSPSS): The MSPSS is a scale developed in 1988 by Zimet et al., ${ }^{49}$ who subjectively assess the adequacy of social support from three different sources: "family", "friend" and "a special person". The factor structure, reliability and construct validity of the Turkish form of the scale were performed by Eker and Arkar. ${ }^{50}$ Cronbach's alpha internal consistency coefficients of the scale ranged from 0.80 to 0.95 .

Experiences in Close Relationship Scale: Brennan et al. $^{51}$ developed the Experiences in Close Relationship Scale which measured anxiety and avoidance dimensions in adult attachment.

Fraley et al., ${ }^{52}$ on the other hand, developed 18 anxiety and 18 avoidance items with the highest discrimination levels and developed the Experiences in Close Relationship ScaleII (EICRS-II). Both avoidance and anxiety dimensions have a high level of internal consistency, and the Cronbach alpha coefficients are 0.90 and 0.86 for these dimensions, respectively.

Marital Adjustment Test: It is a scale developed by Locke and Wallace ${ }^{53}$ to measure the quality of marriage. It was adapted to the Turkish 
culture in 1999 by Tutarel Kışlak. ${ }^{54}$ The internal consistency coefficient calculated within the scope of the reliability study was 0.80 . The scale not only measures general marriage satisfaction and quality, but also measures the type of agreement or disagreement with various issues.

Childhood Trauma Questionnaire: The scale was developed by Bernstein et al. ${ }^{55}$ and adapted to Turkish by Aslan and Alparslan ${ }^{56}$ in 1999. It has been developed to measure abuse experiences before the age of 18 years. It was determined that the scale has a factor structure that reflects physical, emotional and sexual abuse, and within the scope of the reliability study, Cronbach alpha internal consistency coefficients are 0.94 for physical abuse, 0.95 for emotional abuse and neglect, and 0.94 for sexual abuse, and 0.96 throughout the scale.

Structured Clinical Interview for DSM-IV Axis I Disorders (SCID-I): It is a clinical interview form structured by First et al. ${ }^{57}$ for DSM-IV Axis-I disorders. Turkish adaption and reliability study were performed by Özkürkçügil et al. ${ }^{58}$

Structured Clinical Interview for DSM-III R Axis II Disorders (SCID-II): The scale developed by al. Spitzer and Williams was adapted to Turkish by Coşkunol et al. ${ }^{59}$ in 1994, and its validity and reliability study was performed. This scale is a semi-structured interview tool applied by the interviewer to investigate personality disorders according to DSM-III diagnostic criteria.

Semi Structured Interview Form: It was prepared by the researcher in order to collect qualitative data. The questions were prepared by considering the 4 functions that were defined by MacPhee et al. ${ }^{39}$ for self-perception of motherhood. The form was created with four titles: to what extent she sees herself as a mother, satisfaction with the role of motherhood, investments related to motherhood, whether she is in balance with motherhood and other roles. In order to check the suitability, understandability and feasibility of the prepared interview form, it was presented to experts (1 psychiatrist and 1 clinical psychologist) for their opinions.

\section{Statistical Analysis}

Quantitative data of the research were transferred to the SPSS 22 program, T-Test for the parametric statistics, Anova test, Chi-Square Test for nonparametric statistics and Kruskal Wallis Test, and descriptive analysis method was used in the analysis of qualitative data. The mothers' views on parenting perceptions were given directly under the main themes of parenting competence, satisfaction, investment and role balancing. The opinions of the participants were conveyed on the basis of confidentiality by using nicknames.

\section{Results}

\section{The Sociodemographic Characteristics of Mothers}

The findings regarding the sociodemographic characteristics of the mothers in the study are given in Table I. There is a statistically significant difference in the age and perceiving the income levels between the mothers who neglected their children and the mothers of the control group. There was no significant difference between the education levels of the mothers, family structures, the age, number and gender of their children. According to independent $t$ test results $(t(60)=2.49 \mathrm{p}<.05)$, the average age of mothers who neglected their children $(\bar{X}=30.40)$ was lower than the control group mothers $(\bar{X}=$ 33.96) and they perceived their income levels as worse $\left(\chi^{2}(1)=5.27 \mathrm{p}<.05\right)$.

\section{The Variables of Mothers}

When we examined the variables of mothers (Table II.), the difference between the mean scores of the mothers' marital adjustment was significant $(F 1 ; 60)=26,663 ; p<.05)$, the marital adjustment of mothers of neglected children $(\bar{X}$ $=26.06)$ was found to be more negative than that of the control group mothers $(\bar{X}=43.23)$. There was a difference between mean scores of family support $(\mathrm{F} 1 ; 60)=40.780 ; \mathrm{p}<.05)$, a special person's support $(\mathrm{F} 1 ; 60)=84.067 ; \mathrm{p}$ $<.05)$ and friend's support $(\mathrm{F} 1 ; 60)=17.761$; 
Table I. Sociodemographic characteristics of mothers and their children.

\begin{tabular}{|c|c|c|c|c|c|}
\hline \multirow[t]{2}{*}{ Variables } & \multicolumn{2}{|c|}{$\begin{array}{l}\text { Mothers of neglected children } \\
\qquad(\mathrm{n}=32)\end{array}$} & \multicolumn{2}{|c|}{$\begin{array}{l}\text { Mothers of control group } \\
\qquad(\mathrm{n}=30)\end{array}$} & \multirow[t]{2}{*}{$\chi^{2}$} \\
\hline & $\mathrm{N}$ & $\%$ & $\mathrm{~N}$ & $\%$ & \\
\hline \multicolumn{6}{|c|}{ Education level of mothers } \\
\hline Primary school & 15 & 46.9 & 11 & 36.7 & \multirow{3}{*}{$\chi^{2}(6)=2.39$} \\
\hline Secondary school & 10 & 31.3 & 7 & 23.3 & \\
\hline High school & 7 & 21.8 & 12 & 40.0 & \\
\hline \multicolumn{6}{|l|}{ Family structure } \\
\hline Extended & 27 & 84.4 & 23 & 76.7 & \multirow{2}{*}{$\chi^{2}(1)=0.589$} \\
\hline Nuclear & 5 & 15.6 & 7 & 23.3 & \\
\hline \multicolumn{6}{|l|}{ Perceived income level } \\
\hline Middle & 12 & 37.5 & 20 & 66.6 & \multirow{2}{*}{$\chi^{2}(1)=5.27^{* *}$} \\
\hline High & 20 & 62.5 & 10 & 33.4 & \\
\hline \multicolumn{6}{|l|}{ Number of chidren } \\
\hline 1 & 10 & 31.25 & 4 & 13.3 & \multirow{3}{*}{$\chi^{2}(1)=2.84$} \\
\hline 2 & 12 & 37.5 & 14 & 46.7 & \\
\hline 3 and more & 10 & 31.25 & 12 & 40.0 & \\
\hline \multicolumn{6}{|l|}{ Gender of children } \\
\hline Female & 13 & 40.6 & 15 & 50.0 & \multirow{2}{*}{$\chi^{2}(1)=0.550$} \\
\hline Male & 19 & 59.4 & 15 & 50.0 & \\
\hline \multirow[t]{2}{*}{ Age of mothers } & Mean & SD & Mean & SD & \multirow{2}{*}{$t(60)=2.49^{* *}$} \\
\hline & 30.40 & 6.5 & 33.96 & 4.3 & \\
\hline \multirow[t]{2}{*}{ Children's age } & Mean & SD & Mean & SD & \multirow{2}{*}{$t(60)=227$} \\
\hline & 3.63 & 1.4 & 3.70 & 1.4 & \\
\hline
\end{tabular}

$\mathrm{p}<0.01 \quad{ }^{* *} \mathrm{p}<0.05 \quad$ SD: standard deviation $\quad \chi^{2}$ :Chi-square

$\mathrm{p}<.05)$ perceived by mothers. Social support perceived by the mothers of neglected children was found to be more negative. In the mothers of neglected children anxious attachment (F1; $60)=12.513 \mathrm{p}<0.05)$ and avoidant attachment $(\mathrm{F} 1 ; 60)=10,268 ; \mathrm{p}<0.05)$ was observed more. When the childhood traumatic experiences of mothers were evaluated, there was a significant difference between the mean scores of physical abuse $(\mathrm{F} 1 ; 60)=17.880 \mathrm{p}<0.05)$ and emotional abuse $(\mathrm{F} 1 ; 60)=17,397 \mathrm{p}<0.05)$.

Looking at Table III, it was found that the difference between the mean scores of sexual abuse of the mothers in both groups was not significant $\left(\chi^{2}(1)=.113, \mathrm{p}>0.05\right)$. According to these results, it is understood that the mothers of neglected children experience more physical and emotional abuse during childhood.
In the evaluation made with the semi-structured interview form in mothers, the results regarding whether there was a mental illness and personality disorder are given in Table IV.

\section{The Parenting Perceptions of Mothers}

Interviews were made with the mothers of the neglected children to understand their parenting perceptions by using semi-structured questions based on four themes (how adequate they consider themselves as a mother, their satisfaction with maternity role, their investment in maternity, whether they balance maternity and other roles) created by McPhee et al. ${ }^{39}$

Some sub-themes were formed in line with the mothers' narratives (Table V). 
Table II. Comparison of maternal psychosocial characteristics.

\begin{tabular}{|c|c|c|c|c|c|}
\hline & Source of variance & Total sum of squares & SD & Mean square & $\mathrm{F}$ \\
\hline & Between Groups & 4565.226 & 1 & 4565.226 & \\
\hline \multirow{3}{*}{ Marital Adjustment } & In-Groups & 10273.242 & 60 & 171.221 & $26.663^{*}$ \\
\hline & Total & 14838.468 & 61 & & \\
\hline & Between Groups & 1205.324 & 1 & 1205.324 & \\
\hline \multirow[t]{3}{*}{ Family Support } & In-Groups & 1773.385 & 60 & 29.556 & $40.780^{*}$ \\
\hline & Total & 2978.710 & 61 & & \\
\hline & Between Groups & 1672.053 & 1 & 1672.053 & \\
\hline \multirow[t]{3}{*}{ Special Person Support } & In-Groups & 1193.367 & 60 & 19.889 & $84.067^{*}$ \\
\hline & Total & 2865.419 & 61 & & \\
\hline & Between Groups & 216.293 & 1 & 216.293 & \\
\hline \multirow[t]{3}{*}{ Friend Support } & In-Groups & 730.675 & 60 & 12.78 & $17.761^{*}$ \\
\hline & Total & 946.968 & 61 & & \\
\hline & Between Groups & 9489.630 & 1 & 9489.630 & \\
\hline \multirow[t]{3}{*}{ Avoidant Attachment } & In-Groups & 55449.919 & 60 & 924.165 & $10.268^{*}$ \\
\hline & Total & 64939.548 & 61 & & \\
\hline & Between Groups & 5324.449 & 1 & 5324.449 & \\
\hline \multirow[t]{3}{*}{ Anxious Attachment } & In-Groups & 25530.019 & 60 & 425.500 & $12.513^{* *}$ \\
\hline & Total & 30854.468 & 61 & & \\
\hline & Between Groups & 2339.382 & 1 & 2339.382 & \\
\hline \multirow[t]{3}{*}{ Physical Abuse } & In-Groups & 7850.167 & 60 & 130.836 & $17.880^{*}$ \\
\hline & Total & 10189.548 & 61 & & \\
\hline & Between Groups & 4754.363 & 1 & 4754.363 & \\
\hline \multirow[t]{2}{*}{ Emotional Abuse } & In-Groups & 16397.185 & 60 & 273.286 & $17.397^{*}$ \\
\hline & Total & 21151.548 & 61 & & \\
\hline
\end{tabular}

${ }^{*} \mathrm{p}<0.01 \quad{ }^{* *} \mathrm{p}<0.05$ SD: standard deviation

OCD: Obsessive compulsive disorder

Table III. Mothers' childhood trauma questionnaire sexual abuse subscale scores.

\begin{tabular}{llccc}
\hline Group & N & Mean & SD & $\chi^{2}$ \\
\hline Mothers of neglected children & 32 & 32.03 & 1 & $0.113^{*}$ \\
Mothers of control group & 30 & 30.93 & 1 & \\
\hline
\end{tabular}

${ }^{*} \mathrm{p}>0.05$ SD: standard deviation

\section{Competence}

Some mothers stated that their spouses are not interested in home and the child, their responsibilities are higher and marital problems are the reasons for not showing enough parenting skills:

... We never get along with my husband and I have no interest in taking care of the children because of the marital problems. I do not talk to my children, I do not want to play games. They spend most of their time on television. I feel sorry for not being able to but I'm not guilty of this. ... (Mrs. Dilek)

...I am trying to do my best. For example, a child who does not eat, I force-feed, I try to keep him clean. Cooking and cleaning takes most of my time. My husband is not interested at all. Everything is dependent on me. Sometimes I get stressed, I get confused. I cannot deal with the child when there is stress at home. I put him to sleep until noon. ... (Mrs. Elif) 
Table IV. Psychiatric disorders and personality disorders diagnosed in mothers.

\begin{tabular}{lccccc}
\hline \multirow{2}{*}{ Diagnoses } & \multicolumn{2}{c}{$\begin{array}{c}\text { Mothers of neglected children } \\
(\mathrm{n}=32)\end{array}$} & $\begin{array}{c}\text { Mothers of control group } \\
(\mathrm{n}=30)\end{array}$ & $\chi^{2}$ \\
\cline { 2 - 5 } & $\mathrm{N}$ & $\%$ & $\mathrm{~N}$ & $\%$ & \\
\hline Disorder & & & & & \\
$\quad$ Depression & 6 & 75.0 & 2 & 50.0 & \\
$\quad$ Anxiety & 1 & 12.5 & 2 & 50.0 & \multirow{2}{*}{$1.350 \mathrm{SD}=1$} \\
$\quad$ OCD & 1 & 12.5 & - & - & \\
Total & 8 & 100.0 & 4 & 100.0 & \\
Personality disorder & & & & & \\
$\quad$ Dependent & 3 & 42.9 & - & - & \\
$\quad$ OCD & - & & 2 & 50.0 & \\
$\quad$ Avoidant & 3 & 42.9 & 2 & 50.0 & $0.774 \mathrm{SD}=1$ \\
$\quad$ Histrionic & 1 & 14.3 & - & - & \\
Total & 7 & 100.0 & 4 & 100.0 & \\
\hline
\end{tabular}

p>0.05 SD: standard deviation $\quad \chi^{2}$ :Chi-square

OCD: Obsessive compulsive disorder

Table V. Distribution of how mothers of neglected children evaluate their parenting perceptions.

\begin{tabular}{lll}
\hline Main theme & Sub-theme & $\mathrm{N}$ \\
\hline \multirow{3}{*}{ Competence as a mother } & Sense of incompetence & 4 \\
& Competent & 2 \\
& Indecision & 2 \\
& Some conditions must be met & 3 \\
& Complicated feelings & 1 \\
Satisfaction as a mother & Abundance of difficulties & 2 \\
& Regret giving birth to children & 2 \\
Investments related to motherhood & Good sense & 2 \\
& Not need & 5 \\
Balancing the roles of mothers & Need & 3 \\
& Roles imbalanced & 7 \\
\hline
\end{tabular}

A mother stated that it was difficult for her to find time and give care to her child. She stated that she did not want to do so even if she had enough time: ...I can play games with my child, I can take more care of him. Actually, I have time for this. But I feel lazy to do these things. I don't want to do it either. I just want to lie down. I cook, I do housework and cleaning. I think these are enough for motherhood, but children want more. She wants compassion, she wants to play a game. My daughter is angry with me and she says: "You don't love me." We have problems with my husband, I am very unhappy. I also shout very much to my child. I am not a competent mother when I think about these. ... (Mrs. Zeynep) Two mothers stated that they found themselves competent. However, these mothers described competent motherhood as only meeting their children's physical needs such as food and hygiene, and to do whatever they want to prevent their children from getting upset:

...I'm a good enough mother. I cook my child's food, I keep their clothes clean, I do whatever they want so that they do not get upset, so it does not offend to me. ... (Mrs. Ayşe) 
...I have four children, the eldest is 8, and the youngest is 3 years old. All of them can take care of themselves. They don't want anything from me anyway. I help them to take a bath, I cook. They eat their own food without help. They also help me with housework. There is nothing I have difficulty as a mother, I am enough for my children. ... (Mrs. Gulsen)

\section{Satisfaction}

Some of the mothers stated that some conditions must be fulfilled in order to take pleasure from motherhood. They stated that motherhood is not enjoyable for them due to absence of these conditions at the moment and they face with more difficult aspects of motherhood: ...If I had been in a beautiful environment, I had no problems with my husband, motherhood would have been a nice feeling, but now I do not feel that way at all. I wish I hadn't given birth. ... (Mrs. Dilek)

...I didn't want to be a mother. I got married out of obligation. My pregnancy was unplanned. When there was a mother-in-law and a father-inlaw at home, he became a friend to me. It made me move away from home a bit, but the tough parts of motherhood is more. ... (Mrs. Elif)

Some mothers expressed the characteristics their children should have in order to get satisfaction from motherhood: ...Motherhood is a good feeling if she doesn't want to go wrong and have everything she wants. But I have difficulties because of her constant claims. ... (Mrs. Zeynep)

...It is good to be a mother if he does not irritate me, does not have a temper, stubbornness. I want him to show himself in the community and not to be shy. But in these aspects, mother-hood was not what I expected. ... (Mrs. Belma)

Mrs. Arzu complained about the unhappiness she experienced by motherhood limiting her and preventing her from fulfilling her wishes with the following expressions: ...I wish I had lived my life first, had waited 4-5 years, and had given birth after that. Sometimes I wish I gave birth to a stone instead of a child.... (Mrs. Arzu)

\section{Investment}

It was found that mothers do not have behaviors such as reading, researching about motherhood and child development. Mostly, they behave in line with what they see from their families, and some mothers believe that the child will grow spontaneously:

... I have no time to read or learn anything, I don't need to. I prefer to do what I see from my environment. ... (Mrs. Belma)

...We were nine siblings. I am rising my children just as my mother raised us. ... (Mrs. Gulsen)

...I have never done research or reading about childcare. I did not think of it, I said the child grows by itself. I didn't ask anyone either... (Mrs. Arzu)

\section{Balancing Roles}

It is remarkable that mothers stated that they take all the time and energy to do housework and that they do not have time to do anything else while doing housework. It is understood that these housewives spent more time with housework such as cleaning and cooking than time to take care of their children. Expressions of mothers are given below:

...I spent most of my time doing housework. All my energy goes to household chores. I do not take time for myself, nor do anything with my children. ... (Mrs. Zeynep)

...Most of my time passes by doing cooking, clearing the table, washing the dishes. It is important for me to cook and feed my child. I'm always in the kitchen. After dinner, cleaning comes.... (Mrs.Ayşe)

... More time goes to household chores. The whole day goes by cleaning. You have no time for other things.... (Mrs. Sevda)

...It is hard to do household chores and take care of children. He makes the house very dirty, I can never let him. He always comes near me while doing business. It makes me very angry. I want him to play with his toys on his own. I have to take care of the housework. If I take care of the child, housework 
remains. It takes me a lot of time to eat. He wants his own food, but I can't allow it because he pollutes the house. I force him under my arm and put food in his mouth. There is no time for anything other than dealing with these.... (Mrs. Elif)

The most striking results among the qualitative findings were that mothers stated that they could not take care of their children due to the problems they had with their spouses, that their spouses did not help them. They had too many duties and responsibilities, they could not pay their attention to their children due to marital problems and confusion. As a result they could not be adequate mothers. It has been determined that household chores such as cooking and cleaning for mothers are perceived as a priority and more important than taking care of their children and spending time with them. In addition, understanding that mothers do not have sufficient information about child development and proper parenting are also important results of the qualitative findings.

\section{Discussion}

In this study, the characteristics of the mothers of the children who are neglected are tried to be understood by quantitative and qualitative methods from a holistic perspective. In our study, it was determined that there were differences between the age and perceived income levels of the mothers of neglected children and the control group mothers. On the other hand, there were no differences in the education levels of mothers, the age, number and gender of their children, and the types of families the mothers lived in. In the literature, it is stated that the low level of income, the education level of the mother, being a mother at a young age, and being a single parent are associated with neglect and abuse. ${ }^{5,12-15,20}$ In his study with adolescent mothers, Barlet stated that whether these mothers had abusive experiences and whether they received good care during childhood is more of a determinant in their neglect behaviors compared to being young mothers. Similarly, in our study, it was found that there were more traumatic experiences during their childhood among the mothers who neglected their children. Although physical neglect is generally associated with poverty, it is observed that parents who receive financial support continue to neglect their children emotionally ${ }^{61}$ Despite the strong relationships between poverty and child neglect, low income alone does not fully explain this result. It is stated that although the adverse effects of financial difficulties on parents is known, income should not be handled alone, and variables such as parental self-efficacy and social support should be investigated together with variables that are thought to influence the effect of parental stress. ${ }^{62,63}$ In our study, it was found that social support was perceived more negatively among the mothers who neglected their children in accordance with the literature.

According to the findings of our study, it was observed that mothers who neglected their children had poor marital adjustment, perceived inadequate social support, experienced more physical and emotional abuse during childhood, and had more anxious and avoidant attachment patterns. In addition, it was found that there was no difference between mothers in terms of psychiatric disorder, personality disorder and sexual abuse in childhood. Paavilainen and Astedt-Kurki ${ }^{64}$ stated that families with neglect and abuse have a complex family structure. Unresolved problems, differences of opinion and violence are common in these families. Davies et al. ${ }^{29}$ stated that parents who have marital problems cannot pay attention to the needs of their children. Parents who have marital problems and neglect their children are not sufficiently organized. ${ }^{30}$ Coohey $^{65}$ stated that mothers who neglect their children define their relationships with their spouses more negatively and spend less time with their spouses than other mothers. The fact that negligent mothers in our study stated that they had more marital problems, that their communication with their children was inadequate, and that they did not spend qualified time with their children, is consistent with this information in the literature. There are 
studies indicating that having adequate social support will reduce the stressful lives of mothers and this will positively affect the mothers' parenting attitudes and skills, facilitate their coping and reduce their neglect behavior..$^{21-25}$ The fact that social support perceived by the mothers who neglected their children were more negative in our study supports this information. It was found that mothers who neglected their children were diagnosed with psychiatric and personality disorders more frequently than the control group mothers, but the difference between the two groups was not statistically significant. It is stated in the literature that maternal psychopathology causes a decrease in the quality of childcare. Most of the mothers with psychiatric disorders abuse or neglect their children, and most of the mothers who show neglect behavior have a lifelong history of psychiatric disorder ${ }^{26-28}$ As the most powerful determinants of child neglect, antisocial personality traits and using alcohol or drugs are described. However, these diagnoses were not detected in the mothers in our study.

Mothers who stated that they were neglected and abused by their own parents in their childhood neglect their children more and show more negative behaviors towards their children. ${ }^{34-38}$ In our study, the fact that mothers who neglected their children stated that they experienced more physical and emotional abuse in their childhood is in line with literature. In the intergenerational transfer of maltreatment experienced in childhood, it is mentioned about learning by imitation, justifying the parenting style of parents and using it in their own parenting practices. $12,66,67$ The effect of neglect and abuse experienced in childhood can continue throughout life. Without treatment, it can cause serious damage to the health of the mother and child after delivery, which is a particularly sensitive period. ${ }^{68}$ Oshri stated that childhood maltreatment is a risk factor for insecure attachment. ${ }^{69}$ In addition, Widom et al. ${ }^{70}$ stated that physical abuse and neglect in childhood are associated with anxious attachment, depression, anxiety and low self- esteem in adulthood. In this study, the presence of more anxious and avoidant attachment patterns among mothers who neglected their children compared to other mothers supports this relationship between childhood traumatic experiences and adulthood attachment disorders.

According to qualitative findings, most of the mothers who neglected their children had negative transmissions related to parental perceptions. In the literature, mothers with a sense of parental competence will be able to demonstrate appropriate parental behaviors that will support the development of their children, they will establish a more sensitive, warm and mutual relationship with their children. ${ }^{40,43,44,71}$ Mothers who have low parental competence are not interested in their children, and mistreat their children more. ${ }^{42,72}$ The sense of competence affects the choice of behavior and helps to determine how much time, energy and effort a person will spend in parenting. ${ }^{44}$ The mothers in our study did not mention the issues that are extremely important in the healthy development of children, such as establishing a positive relationship with their children, giving appropriate stimuli, and having a pleasant time with their children. This situation also suggests that mothers who neglect their children may have insufficient information about children's needs and development. The existence of life stresses (such as marital conflict, low family income) and whether they have effective coping skills and social supports affect parenting behaviors. ${ }^{39,73,74}$ Consistent with this information in the literature, most of the participants, who did not find themselves competent as a mother, stated that they could not take care of their children due to the problems they had with their spouses. Their spouses did not help them, they were too responsible, could not pay any attention to their children, they were confused and therefore could not be adequate mothers. In the quantitative part of the study, it is understood that these data are in parallel with the mothers who neglect their children find their marital adjustment more negative than the control group mothers. 
It is understood from the mothers' statements that most of the mothers who neglected their children were not satisfied with their motherhood. According to Lerner and Galambos, ${ }^{75}$ feeling satisfied from the role of motherhood is an important indicator in mother-child relationship and being a positive parent. According to Corwyn and Bradley, ${ }^{76}$ obtaining information about child development, making choices suitable for the benefit of the child, spending pleasant time with the child are examples of parent investments. In our study, the majority of mothers stated that they did not read any information about child care, child development or how to behave as a mother. They did not research and did not need these issues. Maintaining motherhood role and other roles in a balanced way is very important for child development. ${ }^{75}$ It is remarkable that the mothers stated that they spent all their time and energy to housework and that they could not spare time for other things due to housework. It is understood that these mothers, who are housewives, give priority in housewife roles such as cleaning and cooking, and that they see domestic affairs as their main and most important duties. Barnett ${ }^{77}$ states that women with different roles have better mental and physical health, and it is not satisfying for some women to perform roles such as housewife and spouse. He also states that working outside the home can be satisfying for women, which will enable women to fulfill their roles more effectively and to have a better qualified relationship with their children. According to Bornstein, ${ }^{44}$ there is a mutual relationship between the feelings of their mothers, their satisfaction with parenting and the balancing of roles. Mothers who balance their roles increase their satisfaction from parenting, which increases their sense of competence. It is compatible with these findings that most of the participants have problems in balancing their parenting competencies, parenting satisfaction and roles.

It was determined that most of the participants had negative experiences in the fields of competence, satisfaction, investment and balancing roles, which constitute the four dimensions of the perception of motherhood. It is thought that this situation will directly or indirectly affect parenting skills and the healthy development of their children and will have an effect on neglect behavior. These variables, which are important in child neglect, should be evaluated from a holistic point of view, considering their relationships with each other. The traumatic experiences of mothers in their childhood may cause anxious and avoidant attachments in adulthood, difficulties in social and marital relations, and neglect of children. Moreover, the inability of mothers to get adequate support from their spouses and their surroundings, cultural household chores as a priority for mothers, and the fact that mothers do not have enough information about child development can also affect mothers' perception of parenting and affect child neglect.

In this research, the fact that only the neglect cases identified at the university hospital were taken and the relatively few participants were included in the study, limit the generalization of the results. Evaluating only mothers is another limitation in this research. It is among the limitations of the study that "Graded Care Profile", which is a descriptive, categorical tool, has not been examined for the 'inter-observer/ rater reliability for our country. Focusing on mothers can lead to improperly accusing and labeling mothers. Neglect studies with father samples should be done, then fathers can be made a part of the solution. Further research is needed to understand the relationship between children's characteristics and neglect, as some of the difficulties and disabilities of children will also affect maternal behavior. Children of the mothers participating in the study were all in pre-school period. Research findings cannot be generalized for all age periods, as the needs of age-specific children and mothers' behavior may vary. It is also important to conduct neglect studies in different age groups, as neglect types may vary depending on the child's developmental stages and the family's ability to meet developmental needs specific to different age group. 


\section{REFERENCES}

1. Dubowitz H, Pitts SC, Litrownik AJ, Cox CE, Runyan D, Black MM. Defining child neglect based on child protective. Child Abuse Negl 2005; 29: 493-511.

2. Hildyard KL, Wolfe DA. Child neglect: developmental issues and outcomes. Child Abuse Negl 2002; 26: 679-695.

3. Crouch JL, Milner JS. Effects of child neglect of children. Crim Justice Behav 1993; 20: 49-65.

4. Trickett PK, McBride Chang C. The developmental impact of different forms of child abuse and neglect. Dev Rev 1995; 15: 311-337.

5. Beissel CF. Observations of neglectful mothers and their children: towards an understanding of maternal attributions. Graduate Program in Psychology Faculty of Graduate Studies, Degree of Doctor of Psihosoph. London: The Universiy of Western Ontario, 2007: 97-123.

6. Shipman K, Edwards A, Brown A, Swishe L, Jennings E. Managing emotion in a maltreating context: a pilot study examining child neglect. Child Abuse Negl 2005; 29: 1015-1029.

7. Davidson-Arad B, Benbenishty R, Chen W, Glasser S, Zur S, Lerner-Geva L. Distinguishing neglect from abuse and accident: analysis of the case files of a hospital child protection team in Israel. Health Soc Care Community 2010; 18: 614-623.

8. Schore AN. Dysregulation of the right brain: a fundamental mechanism of traumatic attachment and the psychopathogenesis of posttraumatic stress disorder. Aust N Z J Psychiatry 2002; 36: 9-30.

9. Welch GL, Bonner BL. Fatal child neglect: characteristics, causation, and strategies for prevention. Child Abuse Negl 2013; 37: 745-752.

10. Hornor G. Child neglect: assessment and intervention. J Pediatr Health Care 2014; 28: 186-192.

11. Schumacher JA, Slep AMS, Heyman RE. Risk factors for child neglect. Aggress Violent Behav 2001; 6: 231254.

12. Chitiyo RA. Predictors of child neglect: mothers' parentification, stress, marital status, education and financial situation. The Faculty of the Graduate School Degree of Doctor of Philosophy. Cookevill: Tennessee Technological, 2014: 62-72.

13. Dursunkaya D. Duygusal örselenme ve ihmal. . İçinde: Çudadoroğlu Çetin F (ed). Çocuk ve Ergen Psikiyatri Temel Kitabı (1.Baskı) Ankara: Çocuk ve Ergen Ruh Sağlığı Derneği Yayınları, 2008: 478-487.
14. Tuna S. Aile içi çocuk istismarı: annelerin bazı risk faktörleri açısından incelenmesi. Yüksek Lisans Tezi, Sosyal Bilimler Enstitüsü, Eğitim Bilimleri Anabilim Dal1, İstanbul Üniversitesi, 2010: 228-235.

15. Whipple EE, Webster-Stratton C. The role of parental stress in physically abusive families. Child Abuse Negl 1991; 15: 279-291.

16. Scannapieco M, Connell-Carrick K. Correlates of child maltreatment among adolescent mothers with young children. J Evid Inf Soc Work 2016; 13: 59-75.

17. Sedlak AJ, Broadhurst DD. The Third National Incidence Study of Child Abuse and Neglect (NIS3) U. S. Department of Health and Human Services, National Center on Child Abuse and Neglect, Washington, 1996.

18. Sedlak AJ. Risk factors for the occurrence of child abuse and neglect. J Aggress Maltreat Trauma 1997; 1: 149-187.

19. Lee BJ, Goerge RM. Poverty, early childbearing, and child maltreatment: a multinomial analysis. Child Youth Serv Rev 1999; 21: 755-780.

20. Brown J, Cohen P, Johnson JG, Salzinger S. A longitudinal analysis of risk factors for child maltreatment: findings of a 17-year prospective study of officially recorded and self-reported child abuse and neglect. Child Abuse Negl 1998; 22: 10651078.

21. Crnic KA, Greenberg MT, Ragozin AS, Robinson NM, Basham RB. Effects of stress and social support on mothers and premature full-term babies. Child Dev 1983; 54: 209-217.

22. Li F, Godinet MT, Arnsberger P. Protective factors among families with children at risk of maltreatment: follow up to early school years. Child Youth Serv Rev 2011; 33: 139-148.

23. Maguire-Jack K, Wang X. Pathways from neighborhood to neglect: the mediating effects of social support and parenting stress. Child Youth Serv Rev 2016; 66: 28-34.

24. Maguire-Jack K, Showalter K. The protective effect of neighborhood social cohesion in child abuse and neglect. Child Abuse Negl 2016; 52: 29-37.

25. Jennings KD, Stagg V, Gonnors RE. Social networks and mothers' interactions with their preschool children. Child Dev 1991; 62: 966-978.

26. Nicholson J, Sweeney EM, Geller JL. Mothers with mental illness: I. the competing demands of parenting and living with mental illness. Psychiatr Serv 1998; 49: 635-642. 
27. Konishi A, Yoshimura B. Child abuse and neglect by mothers hospitalized for mental disorders. Arch Womens Ment Health 2015; 18: 833-834.

28. Egami Y, Ford DE, Greenfield SF, Crum RM. Psychiatric profile and sociodemographic characteristics of adults who report physically abusing or neglecting children. Am J Psychiatry 1996; 153: 921-928.

29. Davies PT, Cummings EM. Marital conflict and child adjustment: an emotional security hypothesis. Psychol Bull 1994; 116: 387-411.

30. Gaudin JM Jr, Polansky NA, Kilpatrick AC, Shilton P. Family functioning in neglectful families. Child Abuse Negl 1996; 20: 363-377.

31. Spilsbury JC, Korbin EJ. Social networks and informal social support in protecting children from abuse and neglect: community ties and supports promote children's safety. Child Abuse Negl 2013; 37(Suppl): 8-16

32. Cobb S. Social support as a moderator of life stress. Psychosom Med 1976; 38: 300-314.

33. Yıldırım İ. Algılanan sosyal destek ölçeğinin geliştirilmesi, güvenirliği ve geçerliği. Hacettepe Üniversitesi Eğitim Fakültesi Dergisi 1997; 13: 81-87.

34. Bulut FI. Genç Anne ve Çocuk İstismarı. Ankara: Bizim Büro Yayınevi, 1996: 195.

35. Bartlett JD, Easterbrooks MA. The moderating effect of relationships on intergenerational risk for infant neglect by young mothers. Child Abuse Negl 2015; 45: $21-34$

36. Pasalich DS, Cyr M, Zheng Y, McMahon RJ, Spieker SJ. Child abuse history in teen mothers and parentchild risk processes for offspring externalizing problems. Child Abuse Negl 2016; 56: 89-98.

37. Éthier LS, Lacharité C, Couture G. Childhood adversity, parental stress, and depression of negligent mothers. Child Abuse Negl 1995; 19: 619632 .

38. Moehler E, Biringen Z, Poustka L. Emotional availability in a sample of mothers with a history of abuse. Am J Orthopsychiatry 2007; 77: 624-628.

39. MacPhee D, Benson JB, Bullock D. Influences on maternal self-perceptions. Paper presented at the Fifth Biennial International Conference on infant studies. Los Angles, 1986.

40. Aksoy V, Diken Hİ. Annelerin ebeveynlik öz yeterlik algıları ile gelişimi risk altında olan bebeklerin gelişimleri arasındaki ilişkiyi inceleyen araştırmalara bir bakış. Ankara Üniversitesi Eğitim Bilimleri Fakültesi Özel Eğitim Dergisi 2009; 10: 59-68.
41. Güler M, Yetim Ü. Ebeveyn rolüne ilişkin kendilik algısı ölçeği: geçerlik ve güvenirlik çalışması. Türk Psikoloji Yazıları 2008; 11: 34-43.

42. Teti DM, Gelfand DM. Behavioral competence among mothers of infants in the first year: the mediational role of maternal self-efficacy. Child Dev 1991; 62: 918-929.

43. Coleman PK, Karraker KH. Self efficacy and parenting quality: findings and future applications. Dev Rev 1998; 18: 47-85.

44. Bornstein MH, Cote LR. Cultural and parenting cognitions in acculturating cultures, 2. patterns of prediction and structural coherence. J Cross Cult Psychol 2003; 34: 350-373.

45. Lerner JV, Hess LE, Tubman J. Maternal employment, maternal role satisfaction and early adolescent outcomes. Baltimore, The Society for Research in Child Development Meeting, April 23-26, 1987. Available at: https://eric.ed.gov/?id=ED286655 (Accessed on 27 June 2018).

46. World Health Organization (WHO). World report on violence a $\mathrm{n} d$ health. Available at: https://apps.who.int/iris/ bitstream/handle/10665/42495/9241545615_eng. pdf?sequence=1 (Accessed on 27 June 2018).

47. Srivastava OP, Polnay L. Field trial of graded care profile (GCP) scale: a new measure of care. Arch Dis Child 1997; 76: 337-340.

48. Polnay L, Srivastava OP. Graded care profile (GCP) A Qualitative Scala for Measure of Care of Children. Luton: Luton Child Protection Committee Press, 2000: $1-5$.

49. Zimet GD, Dahlem NW, Zimet SG, Farley GK. The multidimensional scale of perceived social support. J Pers Assess 1988; 52: 30-41.

50. Eker D, Arkar H. Çok boyutlu algilanan sosyal destek ölçeğinin faktör yapısı, geçerlik ve güvenirliği. Türk Psikoloji Dergisi 1995; 10: 45-55.

51. Brennan KA, Clark CL, Shaver PR. Self report of measurement of adult attachment: an integrative overview. In: Simpson JA, Rholes WS (eds). Attachment Theory and Close Relationships. New York: Guilford Press, 1998: 46-76.

52. Fraley RC, Waller NG, Brennan KA. An item response theory analysis of selfreport measures of adult attachment. J Pers Soc Psychol 2000; 78: 350365.

53. Locke JH, Wallace KM. Short marital-adjustment and prediction tests: their reliability and validity. Marriage Fam Living 1959; 21: 251-255. 
54. Tutarel Kışlak Ş. Evlilikte uyum ölçeğinin (EUÖ) güvenirlik ve geçerlik çalışması. 3P Dergisi 1999; 7: 50-57.

55. Bernstein DP, Fink L, Handelsman L, et al. Initial reliability and validity of a new retrospective measure of child abuse and neglect. Am J Psychiatry 1994; 151: 1132-1136.

56. Aslan SH, Alparslan ZN. Çocukluk örselenme yaşantıları ölçeğinin bir üniversite öğrencisi örnekleminde geçerlik, güvenirlik ve faktör yapısı. Türk Psikiyatri Dergisi 1999; 10: 275-285.

57. Gorgens AK. Structured clinical interview for DSMIV (SCID-I/SCID II). In: Kreutzer JS, Deluca J, Captan B (eds) Encyclopedia of Clinical Neuropsychology (2011 ed) New York: Springer-Verlag.

58. Özkürkçügil A, Aydemir Ö, Yıldız M, Esen Danacı A, Köroğlu E. DSM-IV eksen I bozuklukları için yapılandırılmış klinik görüşmenin Türkçe’ye uyarlanması ve güvenirlik çalışması. İlaç ve Tedavi Dergisi 1999; 12: 233-236.

59. Coşkunol H, Bağdiken İ, Sorias S. SCID-II (Türkçe versiyonu) görüşmesinin kişilik bozukluklarındaki güvenirliği. Türk Psikoloji Dergisi 1994; 9: 26-29.

60. Bartlett DJ, Easterbrooks A. Links between physical abuse in childhood and child neglect among adolescent mothers. Child Youth Serv Rev 2012; 34: 2164-2169.

61. Crittenden PM. Child neglect: causes and contributors. In: Dubowitz H (ed). Neglected Children: Research, Practice, and Policy. Thousand Oaks: SAGE Publications, 1999: 47-68.

62. Slack KS. Understanding the risks of child neglect: an exploration of poverty and parenting characteristics. Child Maltreat 2004; 9: 395-408.

63. Raikes HA, Thompson RA. Efficacy and social support as predictors of parenting stress among families in poverty. Infant Ment Health J 2005; 26: 177-190.

64. Paavilainen E, Astedt-Kurki P. Functioning of child maltreating families: lack of resources for caring within the family. Scand J Caring Sci 2003; 17: 139147.

65. Coohey C. Neglectful mothers, their mothers, and partners: the significance of mutual aid. Child Abuse Negl 1995; 19: 885-895.
66. Simons RL, Whitbeck LB, Conger RD, Chyi-in W. Intergenerational transmission of harsh parenting. Dev Psychol 1991; 27: 159-171.

67. Abramovaite J, Bandyopadhyay S, Dixon L. The dynamics of intergenerational family abuse: a focus on child maltreatment and violence and abuse in intimate relationships. J Interdiscip Econ 2015; 27: 160-174.

68. Muzik M, Adsa M, Bonhamb C, Lisa Rosenblum K, Broderick A, Kirk R. Perspectives on trauma informed care from mothers with a history of childhood maltreatment: a qualitative study. Child Abuse Negl 2013; 37: 1215-1224.

69. Oshri A, Sutton TE, Clay-Warner J, Miller JD. Child maltreatment types and risk behaviors: associations with attachment style and emotion regulation dimensions. Pers Individ Dif 2015; 73: 127-133.

70. Widom CS, Czaja SJ, Kozakowski SS, Chauhan P. Does adult attachment style mediate therelationship between childhood maltreatment and mental and physical health outcomes. Child Abuse Negl 2018; 76: 533-545.

71. Bandura A. Self-efficacy mechanism in human agency. Am Psychol 1982; 37: 122-147.

72. Weaver CM, Shaw DS, Dishion TJ, Wilson MN. Parenting self-efficacy and problem behavior in children at high risk for early conduct problems: the mediating role of maternal depression. Infant Behav Dev 2008; 31: 594-605.

73. Belsky J, Rovine M, Taylor DG. The Pennsylvania infant and family development project III: the origins of individual differences in infant mother attachment: maternal and infant contributions. Child Dev 1984; 55: 718-728.

74. Fincham FD. Child development and marital relations. Child Dev 1998; 69: 543-574.

75. Lerner JV, Galambos NL. Maternal role satisfaction, mother-child interaction, child temperament: a process model. Dev Psychol 1985; 21: 1157-1164.

76. Corwyn RF, Bradley RH. Determinants of paternal and maternal investment in children. Infant Ment Health J 1999; 20: 238-256.

77. Barnett RC. Women and multiple roles: myths and reality. Harv Rev Psychiatry 2004; 12: 158-164. 